\title{
Analysis of caesarean section rate using WHO's Robson's 10-group classification system: a hospital based retrospective study
}

\section{Devika V. Desai*, Nigamananda Mishra, Santoshi Prabhu, Vaishali Jadhav, Gayatri Savani}

Department of Obstetrics and Gynecology, Bhabha Atomic Research Centre and Hospital, Anushaktinagar, Chembur, Mumbai, Maharashtra, India

Received: 15 March 2021

Revised: 12 April 2021

Accepted: 13 April 2021

*Correspondence:

Dr. Devika V. Desai,

E-mail: devikadesai1090@gmail.com

Copyright: (C) the author(s), publisher and licensee Medip Academy. This is an open-access article distributed under the terms of the Creative Commons Attribution Non-Commercial License, which permits unrestricted non-commercial use, distribution, and reproduction in any medium, provided the original work is properly cited.

\section{ABSTRACT}

Background: Maternal morbidity and mortality has been an utmost priority worldwide as it is an indicator of healthcare system. In order to bring it down, it has become the need of the hour to decrease the number of caesarean sections as it is one of the most common cause of morbidity among women. Every institution should have an audit to determine the rate of caesarean section and corresponding indications in order to implement new protocols or modify existing ones to improve caesarean section rates.

Methods: All women who underwent caesarean section between time period Jan 2015- Dec 2019 were included. All vaginal deliveries were excluded. Delivery and operative registers, logbooks and online entries were used for data collection in the obstetric and gynecologic department. A retrospective data collection was done, tabulated and entered in excel sheet.

Results: Robson's group 1, group 2, group 5 were the main contributors to overall caesarean section rate. The major indications for caesarean section were found to be as previous caesarean section (33\%), non-progress of labor (22\%) followed by meconium stained liquor, cephalopelvic disproportion both around $10 \%$.

Conclusions: Robson's group 1, group 2, group 5 were the main contributors to the overall caesarean section rate. The major indications for caesarean section were found as previous caesarean section and non-progress of labor. Further studies are needed for comparison and to make amendments to protocols.

Keywords: Caesarean section, Robson's classification, Retrospective study

\section{INTRODUCTION}

Every fifth woman in this world is undergoing caesarean section. ${ }^{1}$ Cut off percentage for caesarean section has not been well defined. Clinical audits will help to determine and make timely interventions to effectively bring down caesarean section rates and morbidity. Robson classification system proposed by WHO in the year 2015 classifies into ten groups of patients who underwent caesarean section which are mutually exclusive.$^{2}$ It has acquired great acceptance in various setting due to ease and appropriate categorization of patients. ${ }^{3,4}$ It has been a worldwide recommendation by World Health
Organization (WHO) and the International Federation of Gynecology and Obstetrics (FIGO) society for standardizing, assessment and uniform comparison. ${ }^{5,6}$

In 1985, World Health Organization (WHO) meeting held in Fortaleza, Brazil, stated that caesarean section (CS) rates higher than $15 \%$ could hardly be justified from a medical standpoint. ${ }^{7}$ At all India level, the CS rate has increased from 2.9 percent of the childbirth in 1992-93 to $7.1 \%$ in $1998-99$ and further rise to $8.5 \%$ in $2005-06$ and a steady rise to $17.2 \%$ in $2015-16$ with an annual average rate of increase of $8 \%$. According to the recent NFHS 4, the average rate of $\mathrm{C}$-section in India is $17.2 \%$ ranging 
Table 1: Robson classification.

\begin{tabular}{|c|c|}
\hline Group & Description \\
\hline 1 & $\begin{array}{l}\text { Nullipara, singleton cephalic, } \geq 37 \text { weeks, } \\
\text { spontaneous labour }\end{array}$ \\
\hline 2 & $\begin{array}{l}\text { Nullipara, singleton ,cephalic, } \geq 37 \text { weeks } \\
\text { A: induced } \\
\text { B:caesarean section before labour }\end{array}$ \\
\hline 3 & $\begin{array}{l}\text { Multipara, singleton, cephalic, } \geq 37 \text { weeks, } \\
\text { spontaneous labour }\end{array}$ \\
\hline 4 & $\begin{array}{l}\text { Multipara, singleton cephalic, } \geq 37 \text { weeks } \\
\text { A: induced } \\
\text { B: caesarean section before labour }\end{array}$ \\
\hline 5 & $\begin{array}{l}\text { Previous caesarean section, singleton } \\
\text { cephalic, } \geq 37 \text { weeks } \\
\text { A: spontaneous labour } \\
\text { B: induced labour } \\
\text { C: caesarean section before labour }\end{array}$ \\
\hline 6 & $\begin{array}{l}\text { All nulliparous breeches } \\
\text { A: spontaneous labour } \\
\text { B: induced labour } \\
\text { C: caesarean section before labour }\end{array}$ \\
\hline 7 & $\begin{array}{l}\text { All multiparous breeches (including previous } \\
\text { caesarean section) } \\
\text { A: spontaneous labour } \\
\text { B: induced labour } \\
\text { C: caesarean section before labour }\end{array}$ \\
\hline 8 & $\begin{array}{l}\text { All multiple pregnancies } \\
\text { A: spontaneous labour } \\
\text { B: induced labour } \\
\text { C: caesarean section before labour }\end{array}$ \\
\hline 9 & $\begin{array}{l}\text { All abnormal lies (including previous } \\
\text { caesarean section but excluding breech } \\
\text { A: spontaneous labour } \\
\text { B: induced labour } \\
\text { C: caesarean section before labour }\end{array}$ \\
\hline 10 & $\begin{array}{l}\text { All singleton cephalic, } \leq 36 \text { weeks (including } \\
\text { previous caesarean section) } \\
\text { A: spontaneous labour } \\
\text { B: induced labour } \\
\text { C: caesarean section before labour }\end{array}$ \\
\hline
\end{tabular}

Source: Robson classification: implementation manual-WHO

from 5.8\% in Nagaland to $58.0 \%$ in Telangana. $45 \%$ underwent caesarean section post onset of labor while $55 \%$ preterm. The difference in C-section delivery from
NFHS-1 (National Family Health Survey) to NFHS-4 shows that 7 states has CS rate that is more than $30 \%$, eight states has CS rate in between $10 \%$ and $20 \%$ and nine states less than $10 \%$. There is an alarming increase in CS rates in India and interstate and regional variations in CS rates. 8The data of NFHS-5 is yet to be released.

Objective of the study was to determine rate of caesarean section and classifying each indication of caesarean section according to Robson's classification.

\section{METHODS}

A retrospective type of study was done in the department of obstetrics and gynecology, Bhabha Atomic Research Centre and Hospital, Mumbai. Study was conducted after appropriate scientific and ethical committee approval. All women who underwent caesarean section between time period January 2015 - December 2019 were included in the study. Data collection was done by referring delivery and operative registers, logbooks and online entries maintained in the department. The obtained data was tabulated into categories for analysis.

\section{Statistical analysis}

Data tabulated in excel sheet and statistical analysis done, results stated in terms of total number, mean and percentages over 5 years (January 2015-Deccember 2019). The results are presented in table form.

\section{RESULTS}

As it is clearly seen, the incidence of emergency sections have been persistently high since past 5 years with an average rate of $60 \%$ emergency sections and $39 \%$ elective sections. Average rate of $49 \%$ caesarean sections over past 5 years.

It is clearly observed that previous caesarean sections (CS), non-progress of labor (NPOL) and meconium stained liqor were the most common indications accounting for $33 \%, 22 \%$ and $10 \%$ respectively.

Rest of indications being cephalopelvic disproportion, meconium stained liqor and malpresentation.

Table 2: Incidence of emergency and elective sections.

\begin{tabular}{|llllllll|}
\hline Year & Total confinements & Emergency CS & $\%$ & Elective CS & $\%$ & Total & $\%$ \\
\hline $\mathbf{2 0 1 5}$ & 420 & 120 & 60.9 & 77 & 39.1 & 197 & 46.9 \\
\hline $\mathbf{2 0 1 6}$ & 451 & 155 & 67.6 & 74 & 32.4 & 229 & 50.7 \\
\hline $\mathbf{2 0 1 7}$ & 411 & 120 & 61.2 & 76 & 38.8 & 196 & 47.6 \\
\hline $\mathbf{2 0 1 8}$ & 441 & 124 & 58.7 & 87 & 41.3 & 211 & 47.8 \\
\hline $\mathbf{2 0 1 9}$ & 475 & 129 & 56.8 & 98 & 43.2 & 227 & 47.7 \\
\hline Total & 2198 & 648 & 61.13 & 412 & 38.86 & 1060 & 48.2 \\
\hline
\end{tabular}


Table 3: Indications of caesarean section.

\begin{tabular}{|lllllllll|}
\hline Year & $\begin{array}{l}\text { Previous } \\
\text { CS }(\mathbf{3 3} \%)\end{array}$ & $\begin{array}{l}\text { CPD } \\
(\mathbf{1 0} \%)\end{array}$ & $\begin{array}{l}\text { NPOL } \\
(\mathbf{2 2} \%)\end{array}$ & $\begin{array}{l}\text { Fetal distress } \\
(\mathbf{8} \%)\end{array}$ & $\begin{array}{l}\text { Meconium } \\
\text { Stained Liqor } \\
(\mathbf{1 0 \%})\end{array}$ & $\begin{array}{l}\text { Oligohydra- } \\
\text { mnious } \mathbf{( 4 \% )}\end{array}$ & $\begin{array}{l}\text { Malpresen- } \\
\text { tation (3\%) }\end{array}$ & $\begin{array}{l}\text { Others } \\
(\mathbf{1 0 \%})\end{array}$ \\
\hline $\mathbf{2 0 1 5}$ & 65 & 19 & 43 & 15 & 20 & 8 & 6 & 21 \\
\hline $\mathbf{2 0 1 6}$ & 75 & 23 & 50 & 18 & 23 & 9 & 7 & 24 \\
\hline $\mathbf{2 0 1 7}$ & 66 & 18 & 40 & 17 & 18 & 7 & 8 & 22 \\
\hline $\mathbf{2 0 1 8}$ & 72 & 22 & 48 & 24 & 17 & 5 & 4 & 19 \\
\hline $\mathbf{2 0 1 9}$ & 73 & 25 & 47 & 20 & 21 & 6 & 8 & 27 \\
\hline Total & 351 & 107 & 228 & 84 & 99 & 35 & 33 & 113 \\
\hline
\end{tabular}

Table 4: Incidence of various groups according to Robson classification.

\begin{tabular}{|ll|}
\hline Group & Incidence $(\%)$ \\
\hline One & 17 \\
\hline Two & 22.1 \\
\hline Three & 3 \\
\hline Four & 4.4 \\
\hline Five & 22.5 \\
\hline Six & 6 \\
\hline Seven & 3.4 \\
\hline Eight & 3.2 \\
\hline Nine & 3.4 \\
\hline Ten & 15 \\
\hline
\end{tabular}

Post data analysis, it was found that robson's group 1,2 and 5 were the most common groups among all when classified according to robson's criteria while rest of groups constituted a small number.

Table 5: Important parameters and respective rates.

\begin{tabular}{|lll|}
\hline Parameter & Group & Percentage \\
\hline Age & $<20$ yrs & 5.2 \\
\hline & $20-35$ & 84.3 \\
\hline Type of CS & $>35$ & 10.5 \\
\hline & Emergency & 62.1 \\
\hline Parity & Elective & 37.9 \\
\hline & Primigravida & 56 \\
\hline Gestational age & Multigravida & 54 \\
\hline & $\begin{array}{l}\text { Preterm }(\leq 36 \\
\text { weeks })\end{array}$ & 22 \\
\hline Onset of labor & Term & 78 \\
\hline & Spontaneous & 48 \\
\hline Presentation & Induction of labor & 52 \\
\hline & Cephalic & 90 \\
\hline & $\begin{array}{l}\text { Breech, } \\
\text { transverse, oblique }\end{array}$ & 10 \\
\hline
\end{tabular}

It can be seen that majority were among age group 20-35 years, women who underwent emergency sections, term gestation and induced labor underwent more caesarean sections when compared to below 20yrs, above 35 years, elective sections, preterm and spontaneous labor.

\section{DISCUSSION}

In order to decrease morbidity associated with rising caesarean section rate, it is indeed important to scrutinize all caesarean sections pertaining to intrapartum course, indications and postoperative recovery.

The maximum contributors of caesarean deliveries in this study were by groups 1, 2 and 5. Similarly, a study in Brazil which is comparable to India in terms of socioeconomic development, women with a history of previous caesarean at term with cephalic presentation (group 5) and primigravidas, cephalic presentation and $>37$ weeks gestation (group 1,2) were the most common groups. ${ }^{9}$

In India as well, a study conducted in a community center has examined caesarean deliveries of over a decade. In it, around 10,093 caesareans were analyzed and all deliveries were classified as per the Robson's system. Accordingly, they found that the largest contributors to total caesarean sections were groups 1, 5 and 3 (37.62\%, $17.06 \%$ and $15 \%$ respectively). This greater number of group 5 and less number of group 2 probably may be explained by the fact that the community centers usually cater to low risk women and have fewer inductions and trial of labor for previous caesarean sections as in India referrals are mostly for high risk pregnancies. ${ }^{10}$

According to a similar study done by Tripathi et al, in New Delhi over a 5 year period data analysis, all women with one or more previous caesareans with cephalic presentation (group 5) contributed to the maximum number of caesareans $(32.5 \%)$, closely followed by group $1(22.86 \%)$ and group $2(10.25 \%) .31 .65 \%$ of the total caesareans were elective cases, $17.23 \%$ were in women with inductions and $51.1 \%$ of the caesareans were in spontaneously laboring women. ${ }^{11}$

In the present study, around $33 \%$ of all caesareans were done for previous caesarean section $22 \%$ for nonprogress of labor and $10 \%$ for meconium stained liquor. 
Some important points needs no less emphasis like labour ward protocols to decrease caesarean section rates at an institutional level keeping in mind the available resources is important. All meconium stained liquors or all nonreassuring fetal heart patterns do not necessarily require a caesarean.

Risk versus benefit needs to be weighed without compromising on maternal and perinatal outcome. More need for adequate training for emergency procedures, operative vaginal deliveries and interpretation of cardiotopograph cannot be less emphasized. Although, fetal blood sampling helps to decrease unnecessary cesareans depicting good condition of fetus in case of abnormal cardiotopograph, fetal scalp stimulation is also useful. $^{12}$

Classification under the Robson's system is the first step on the path to reduce caesarean rates. It is only through regular analysis that relevant group specific measures can be introduced, changes implemented and repeat audit needs to be done to measure the impact. The major drawback of Robson's system is that it does not include the neonatal morbidity or any maternal high risk factors. Thus, ignoring a significant number of caesarean deliveries taking place for maternal or neonatal high risk factors. In this era of patient autonomy, the concept of caesarean on demand also comes as a huge setback for improvement in areas of precious pregnancy and trial of labor for previous caesarean delivery. ${ }^{13}$

Limitation of study was a large study population would give better understanding and help in comparison of studies. Further studies are required to involve perinatal outcome and maternal outcome.

\section{CONCLUSION}

All deliveries and caesareans should be universally categorized by the Robson's system for standardization and comparison. Interventions should be targeted at reducing primary caesareans and encouraging patients for trial of labor for previous caesareans where possible.

Institutional protocols have to be defined, inductions and caesarean deliveries to be done for justified indications. A regular audit should be done in all institutions to rationalize caesarean rates. Impact of interventions to reduce caesarean rates should be studied and documented for future reference.

\section{Funding: No funding sources} Conflict of interest: None declared

Ethical approval: The study was approved by the Institutional Ethics Committee

\section{REFERENCES}

1. Betrán AP, Ye J, Moller AB, Zhang J, Gülmezoglu $\mathrm{AM}$, Torloni MR. The increasing trend in caesarean section rates: global, regional and national estimates: 1990-2014. PLoS One. 2016;11(2):e0148343.

2. Robson M. Classification of caesarean sections. Fetal Maternal Med Rev. 2001;12(1):23-39.

3. Betran AP, Vindevoghel N, Souza JP, Gulmezoglu AM, Torloni MR. A systematic review of the Robson classification for caesarean section: what works, doesn't work and how to improve it. PLoS ONE. 2014;9(6):e97769.

4. Torloni MR, Betran AP, Souza JP, Widmer M, Allen T, Gulmezoglu M, et al. Classifications for cesarean section: a systematic review. PLoS ONE 2011;6(1):e14566.

5. World Health Organization. WHO Statement on Caesarean Section Rates. WHO/RHR/. 2015.

6. FIGO Working Group on Challenges in Care of Mothers and Infants during Labour and Delivery. Best practice advice on the 10-group classification system for cesarean deliveries. Int J Gynaecol Obstet. 2016;135:232-3.

7. World Health Organization. Appropriate Technology for Birth. Lancet. 1985;326(8452):436-7.

8. Radhakrishnan T, Vasanthakumari KP, Babu PK, Vasanthakumari P. Increasing Trend of Caesarean Rates in India: Evidence from NFHS-4. 2017;5(8):26167-76.

9. Bolognani CV, Reis LB, Dias A, Calderon ID. Robson 10-groups classification system to access Csection in two public hospitals of the Federal District/Brazil. 2018;13(2):e0192997. PLoS ONE.

10. Yadav RG, Maitra N. Examining Cesarean Delivery Rates Using the Robson's Ten-group Classification. J Obstet Gynecol India. 2016;66(1):S1.

11. De, A, Tripathi R, Gupta N. Analysis of cesarean sections using Robsons classification system in a tertiary hospital in New Delhi. Ind J Obstet and Gynec Res. 2020;7(1):7-11.

12. Elimian A, Figueroa R, Tejani N. Intrapartum assessment of fetal well-being: a comparison of scalp stimulation with scalp blood $\mathrm{pH}$ sampling Obstet Gynecol. 1997;89(3):373-6.

13. Wingert A, Johnsonc C, Featherstone S, Sebastianski M, Hartling L, R, Wilson RD. Adjucnt clinical interventions that influence vaginal birth after cesarean rates: a systemic review. BMC Pregnancy Childbirth. 2018;18(1):452.

Cite this article as: Desai DV, Mishra N, Prabhu S, Jadhav V, Savani G. Analysis of caesarean section rate using WHO's Robson's 10-group classification system: a hospital based retrospective study. Int J Reprod Contracept Obstet Gynecol 2021;10:2006-9. 